\title{
FATHOM
}

\section{Thomas Hardy, Under the Greenwood Tree}

Edited by Simon Gatrell and Phillip Mallett

Oxford University Press (Oxford World's Classics), 2013

\section{Eric Christen}

\section{Q OpenEdition \\ 1 Journals}

\section{Electronic version}

URL: http://journals.openedition.org/fathom/479

DOI: $10.4000 /$ fathom.479

ISSN: 2270-6798

\section{Publisher}

Association française sur les études sur Thomas Hardy

\section{Electronic reference}

Eric Christen, «Thomas Hardy, Under the Greenwood Tree », FATHOM [Online], 2 | 2013, Online since 28 October 2013, connection on 22 September 2020. URL : http://journals.openedition.org/fathom/479 DOI : https://doi.org/10.4000/fathom.479 


\title{
Thomas Hardy, Under the Greenwood Tree
}

\author{
Edited by Simon Gatrell and Phillip Mallett \\ Oxford University Press (Oxford World's Classics), 2013
}

\section{Eric Christen}

1 If you have never read Under the Greenwood Tree, now is the time. This fine, new edition is a superb opportunity to discover a wonderfully enjoyable "comedy in chapters". In Professor Phillip Mallett's clear and to the point 'Introduction':

Past and present, loss and gain, community ties and individual aspiration, are brought into a satisfying if provisional harmony, and most readers have seen the novel much as J. M. Barrie did in 1889, as not Hardy's "greatest" book but "his most perfect”. (Hardy 2013, xi-xii)

This "rural painting" is musically composed like a concerto grosso in four movements, the parts of the young lovers, Dick and Fancy, interplaying in counterpoint with those of the Mellstock Quire - nature performing the continuo of the four seasons.

Don't rush through the story but take your time to enjoy each page of this, Hardy's shortest novel - with its obvious happy ending in delightful harmony. From the first sentence "To dwellers in a wood..." to the last "... and thought of a secret she would never tell", every evocative passage, every direct or indirect indication of the characters' inner thoughts and feelings, every verbal exchange between them, is a gem, and the whole is as well balanced as a piece of classical music or an old painting, whether Dutch or not, of previous centuries. Several chapters would be worth being quoted in full in anthologies of English literature: "The Tranter's Party", "The Interview with the Vicar" and, in my opinion, all the evocations of nature. Observe how the living elements of nature are harmoniously and delicately interwoven with the thoughts and feelings of the characters, accompanying and supporting them.

Enjoy this "rural painting" of life in an isolated rural community nearly two hundred years ago. Forget for a moment the stress of today's life in crowded cities, then compare the restrained and delicately controlled behaviour and language of Dick and Fancy to those of young lovers today. Note (with Phillip Mallett in his 'Introduction') 
what the elderly married couples actually say to each other. And think of what 'The Knot There's No Untying' may have implied for them, for Hardy's contemporary readers, for Hardy himself - and what the concept as well as the practical institution of marriage have become.

"Rural painting" of an idealised, idyllic world? Well, yes, the novel was intended for a Victorian reading public; however, it was not written by any conventional novelist, but by the penetrating Thomas Hardy, who saw reality as it truly was and is ${ }^{1}$, always with his deep, constant "loving-kindness".

A few sentences from Phillip Mallett's 'Introduction':

To detect a note of melancholy in Under the Greenwood Tree is not to argue that it is a sad or dispiriting work: it is not. Melancholy is not incompatible with pleasure. (Hardy 2013, xxvii)

From the outset, the novel hints that its mood will be one of elegy as well as pastoral comedy. (xxviii)

[...] as the reader closes the book, it is not necessarily the last page which stays in the mind. It might instead be the window-board in Keeper Day's house, "curiously stamped with black circles - burnt thereon by the heated bottoms of drinking-cups which had rested there after previously standing on the hot ashes of the hearth' (p. 85), and hinting at numerous stories told and retold by generations of guests. Like the greenwood tree itself, home over the years to hundreds of birds, its bark nibbled at by tribes of rabbits and hares, providing shelter for families of moles and earthworms, the window-board stands as an emblem of generosity, continuity, and renewal. (xxix)

7 But of course you have already read Under the Greenwood Tree. This is the expected academic, well documented edition, complete with the traditional Map of Wessex, 'Introduction', 'Note on the Text', 'Select Bibliography', 'A Chronology of Thomas Hardy', Hardy's 'Preface of 1912', an appendix on 'Topographical and Associated Revisions of Interest', another on the 'Dutch school of Painting' referred to in the subtitle, and the indispensable 'Explanatory Notes', without which much of what the characters say in their local variety of English would be lost on us, and which have been further completed. These notes are not only useful to understand what is said, but they are a rich source of enjoyment in themselves, as well giving interesting pieces of added information both on life in Wessex at the time and on the novel itself. See for example the first note about page 32:

THE LISTENERS: the original title for the chapter was the title (and first line) of Wordsworth's poem 'She was a Phantom of Delight'. Simon Gattrell argues convincingly that the character of Fancy Day was drawn with Wordsworth's poem in mind (Thomas Hardy and the proper Study of Mankind, 18-19). (Hardy 2013, 188-189)

Among several decisions which had to be made concerning the text itself, Professor Simon Gattrell begins his 'Note on the Text' by stating that

This text of Under the Greenwood Tree uses as its basis the manuscript of the novel, to which are made all the alterations which are probably or certainly Hardy's own; excluded are, so far as is possible, alterations made by compositors without direction from the author. This means that though the words of the novel, with a few interesting exceptions, remain basically the same here as in other texts that are commonly read, the punctuation and paragraphing are quite different - are what 
Hardy wrote, rather than what the compositors thought he should have written. (xxxi)

9 How important! The rhythm of Hardy's prose and the rhythm of the protagonists' ways of speaking are both essential constituting elements of this work of art.

\section{BIBLIOGRAPHY}

Hardy, Thomas, The Life and Work of Thomas Hardy, ed. Michael Millgate, London: Macmillan, 1984.

Hardy, Thomas, Under the Greenwood Tree or The Mellstock Quire. A Rural Painting of the Dutch School, ed. Simon Gatrell \& Phillip Mallett, OUP (Oxford World's Classics), 2013.

\section{NOTES}

1. "I want to see the deeper reality underlying the scenic, the expression of what are sometimes called abstract imaginings." (Hardy 1984, 192)

INDEX

oeuvrecitee Under the Greenwood Tree 